\title{
A Record of Flight Altitude of Whistling Swans
}

by R. W. Nero, Saskatchewan Museum of Natural History

Chester S. Brown (Director, Parks and Recreation Branch, Saskatchewan Deplartment of Natural Re. sources) recentily rellated to me an cibservation made by himself and pilot Earl Dodds of Whistling Swans (Olor columbianus) flying at an altitude of 7,100 feet (above sea level). Some 25 to 30 swans were olbserved flying scutheast (downwind) over Deschambault Lake (50 miles west of Flin Flon) at mid-day on Sepitember 16, 1960. The swans were seen briefly just as the pliane rose above cloud cover consisting of nine-tenths alto cumulus.

F. C. Lincoln has previously pointed out that "Actual knowledge of the altitude of mignatory flight is scanty, though ....accurate data resulting from alitimeter observations from airplanes, are slowly accumulating... During the World Wars broad areas in the air were under constant surveillance and among the airplane pilots and observers many took more than a casual interest in birds. Of the several hundred records resulting frem their observation only 36 were af birds flying above 5,000 feet, and only 7 above 8,500 feet. Cranes were once recorded at an altitude of 15,000 feet..." (1950. Migration of Birds. Circular \#16, U.S. Fish and Wildlife Service, Washington, D.C.)

The present record helps substantiate comments in the literature regarding high altitude flying in this species. According to A. C. Bent (1925. Life Histories of North American Wild Fowl) Whistling Swans "... usually fly rather high, and when travelling are often way up above the clouds." Dozens of Whistling Swans which were found dead in Wisconsin in 1954 were apparently killed by large hailstones while in flight at a very high altitude (H. A. Hochbaum, 1955. Travels and Traditions of Waterfowl. University of Minnesota Presis).

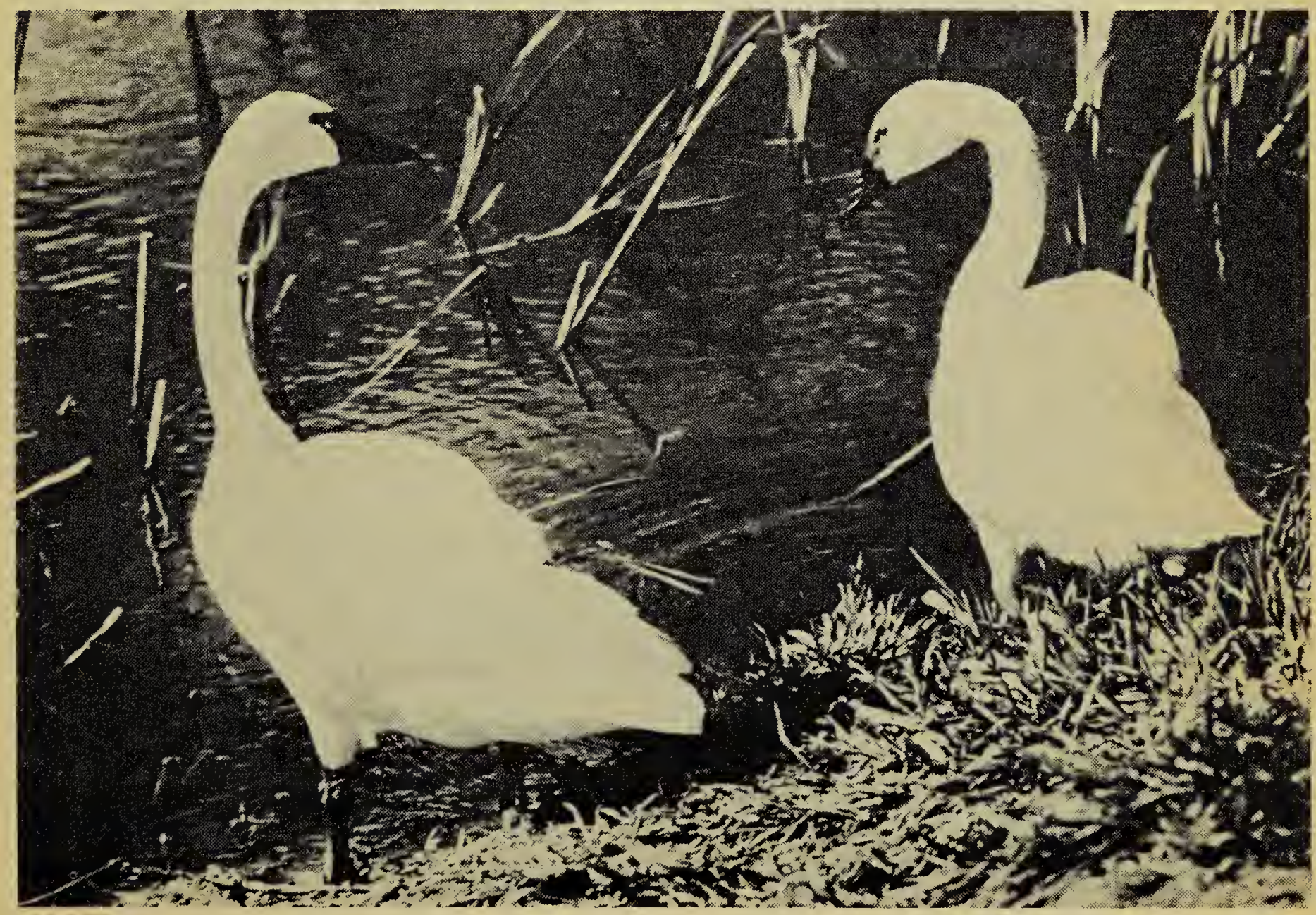

Photo by $F$. W. Lahrman

Whistling Swans in the Regina Waterfowl Park. 